\title{
LIMN-D-19-00006 Limnology (2020) 21: 25-34 Naganawa et al. 和文摘要誤掲載問題についてのお詫び
}

\begin{abstract}
今回、標記和文摘要を陸水学雑誌第81巻2号185-186ページに誤記載いたしました。編集委員長より、著者の皆様に 心よりお詫びし、正しい和文摘要を今回掲載させていただきます。今回の誤りは責任著者より和文摘要が届いている にもかかわらず、不注意により編集局で和訳したものを掲載してしまったものです。今後は学会として再発防止に努 めるよう相互チェック体制を強化いたします。
\end{abstract}

(訂正記事)

Limnology (2020) 21: 25-34 特集：原著論文

Does the dispersal of fairy shrimps (Branchiopoda, Anostraca) reflect the shifting geographical distribution of freshwaters since the late Mesozoic?

世界のホウネンエビ類の分散は中生代後期以降にお ける淡水の地理的分布の推移を反映するか?

長縄秀俊 - Elena Yu. Naumova - Natalia N. Denikina • Ilya G. Kondratov • Elena V. Dzyuba ・岩澤 淳

ホウンネンエビ目（Order Anostraca，大型鰓脚類）は 古代の形態と生態を保持している原始的な甲殼類のグ ループである。とりわけ北半球に広く分布するキタホウ ネンエビ科 Chirocephalidae は1億年以上前に誕生したと され, 中生代から現在まで生き残った非常に長命の淡水 分類群である。したがって，著者らはこの分類群を指 標として利用し, 古代の淡水の地理的分布がどのよう に推移したかの検証を試みた。具体的には，新たに採 取された青森産のDrepanosurus uchidai と, 同じくオリ ホン島（ロシア，バイカル湖最大の島）産の Galaziella baikalensis および Branchinecta orientalis のサンプルを材 料とし，ミトコンドリア COI 遺伝子658塩基対の配列を 決定した。これらの配列に加えて, GenBank のデータ ベースを検索し取得した16S リボソーム RNA 遺伝子(約 550塩基対のミトコンドリア16S リボソーム DNA 断片) の配列も比較対象とした。これまで混同されていたキタ ホウネンエビ科の系統関係を再評価するため, 同科に含 まれると考えられる Polyartemiella 属, Drepanosurus 属,
Eubranchipus 属, Chirocephalus 属, Artemiopsis 属および Galaziella 属の合計6属が, 本研究の分子系統解析に使用 された。小さな水域はふつら比較的短い寿命を示し, 水 生植物の繁茂や水底の堆積物のために遅かれ早かれ消失 する。そのような環境で大型鰓脚類がいくつもの水河期 を生き延びるには，大規模な湖沼の沿岸に形成されたレ フュジア（待避地）の存在が不可欠だった。湖岸線は 湖沼の成長や衰退に伴って移動するが, 散在して取り残 された大型鰓脚類の生息地からは, 今や地球規模におけ る淡水の地理的分布の推移を垣間見ることがでる。例え ば，バイカル湖オリホン島の島内に形成された小水域か

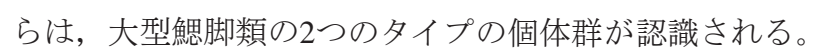
ひとつめは, モンゴルのゴビステップ地域の個体群と形 態的および遺伝的に密接に関連しているオリホン島北西 部沿岸の個体群, そしてふたつめは, オリホン島の内陸 水域に見られる同島固有の個体群である。化石の記録と 遺伝的距離に基づいて, 世界のキタホウネンエビ科の絶 対分化年代は中生代のおよそ1億4,000万年前と推定する ことができる。一方で, バイカル湖の成立はせいぜい 2,500～3,000万年前のことである。したがって，現存す るオリホン島の大型鰓脚類は, ヨーロッパを起源とする それらの祖先形態の集団から分離したのち, バイカル湖 が形成される前に, 現在のバイカル湖の集水域付近の水 域に進出して定着したものと考えなければならない。

キーワード : 大型鰓脚類, ホウネンエビ類, Drepanosurus 属, Galaziella 属, バイカル湖オリホン島 